\title{
Gonad Somatic Index and Feeding Habit of Selected Fish Species of Lake Kalgwaiin Jigawa State, Nigeria
}

\author{
Shola Gabriel S, Victoria Offuene A, Musa Abubakar T and Victor Tosin 0* \\ Department of Fisheries and Aquaculture, University of Agriculture Makurdi, Nigeria
}

Submission: June 16, 2017; Published: July 31, 2017

*Corresponding author: Victor Tosin O, Department of Fisheries and Aquaculture, University of Agriculture Makurdi, Nigeria, Tel: 348033319959

; Email: okomodavictor@yahoo.com

\begin{abstract}
This study investigates gonado somatic index, food and feeding habit of selected fish species of Lake Kalgwai Jigawa State, Nigeria. Samples of fish were collected every fortnight (July 2012-June 2013) at three major landing sites of the lake. The weight of each fish was recorded, gonads were removed, weighed and the gonadosomatic index (GSI) calculated. Stomach was also removed and the content analyzed using frequency of occurrence and point method. Result obtained reveals GSI to range from $2.39 \pm 0.08 \%$ in Nile perch Latesniloticus [1] to $5.92 \pm 0.29 \%$ in Nile tilapia Oreochromisniloticus [1]. The stomach content analysis in this study distinguished the fish species into two major groups; Latesniloticus, Mormyrusmacrophthalmus Günther, 1866 and Bayad bagrus bayad Forsskål [2] were observed to exhibit carnivorous feeding habits and feed predominantly on crustacean, fish, fish parts, mollusks, insects and insect larvae, Oreochromisniloticus, African bony tongue Heterotisniloticus [3], Electric catfish Malapteruruselectricus, Synodotisnigrita and North African catfish Clarias gariepinus on the other hand were observed to have an omnivorous feeding pattern with plant parts, insect parts, detritus, crustaceans, snails, worms, fish parts, insects larvae, sand/mud, and algae dominating their diet. Many of the omnivores encountered in this study have good potential as future aquaculture candidate hence the need to further study their biology and their performance under captivity.
\end{abstract}

Keywords: Feeding Habit; GSI; Man-made lakes; Stomach analysis

\section{Introduction}

Continuous declining inland water catches are indication of low fish yield in many water bodies, the reason for this reduction in fish yield has been linked to inadequate management of fisheries as well as continuous degradation of water bodies Solomon et al. [4]. Many fish resources in Nigeria are currently over-fished and continuous pollution keeps threatening aquatic life and natural habitats [5]. The continuous use of obnoxious fishing practice, deliberate disposal of toxic chemicals and lack of regulation on fishing activities of many aquatic resources of Africa are the reasons for significant reduction in fish yield, loss of aquatic life and habitats destruction Adeyemo [5].

In sub Saharan Africa where fishing is not regulated, domestication and culture of commercially important fish species remains the key to mitigating further decline and possible extinction of important inland fishes Umaru et al. [6], hence the need to focus research on some aspect of the biology of fishes with the aim of domestication. The gonadosomatic index as well a feeding habit are some of the important biological aspect of fishes that needs to be understood for a successful domestication program, gonadosomatic index plays a significant role in evaluating reproductive potential, maturity index [7] as well as gonadal state of a fish Saksena [8]. The food and feeding habits of fish on the other hand is necessary to understand the welfare and husbandry requirements in the wild and adopting same in captivity so as to make domestication of fish a success. Pius and Benedicta [9] reported that the assessment of the stomach content of a fish reduce intra and inter specific competition for ecological niche as it is vital in providing straight forward models of stomach content and feeding dynamics.

In the wild, nature offers a great diversity of organisms that are used as food by fish and these differ in size and taxonomic groups. Many studies have been in an attempt to investigate dietary requirements of fish through it feeding habit in the wild Hynes [10], however, depending on the diversity of the nature of food available in different environment, outcome of such investigations may differ due to environmental differences even for the same species. Studies on the biological aspect of aquatic organism such as food and feeding habits are bases for the 
development of successful fisheries management programme, hence the need for continuous research Oronsaye \& Nakpodia [11]. This study therefore examines the gonadosomatic index, food and feeding habits of selected fish species in lake Kalwaijigawa State, Nigeria.

\section{Materials and Methods}

\section{Study area}

The study was conducted at the Kalgwai Barrage Dam situated in Auyo Local Government Area of Jigawa State, Nigeria (Figure 1). The dam was constructed in 1984 by impounding the River Hadeja for the purpose of irrigation. The irrigation was a Federal Government of Nigeriaprogram (Hadejia Valley Irrigation Project) coordinated by the Hadejia-Jama'are River Basin Development Authority (H.J.R.B.D.A). The dam covers an estimated area of $3800 \mathrm{sqkm}^{2}$ Matthes [12]. This has brought an increased fishing activity especially in those villages surrounding the dam site. Currently the importantly exploited fish species of the lake based on economic return of fishermen are Latesniloticus, Mormyrusmacropthalmu, Bagrusbayad, Oreochromisniloticus, Heterotisniloticus, Malapteruruselectricus, Synodotisnigrita and Clarias gariepinus.

\section{Collections of samples}

Fish sample for this study were obtained from fishermen at three major landing sites of the dam, namely Marke (Site I), Dingare (Site II) and Kalgwai (Site III) respectively (Figure 1). The fishing gears used by the fishermen in this study includes; traps, seine nets, cast net, gill nets, clap nets, hook and line, while crafts was basically canoe and calabash. Commercially important fish species (as stated earlier) were randomly sampled at each site fortnightly over a period of ten months (July 2012-June 2013). Sampling time was between 6:00am to 8:00am when fisher men would be returning to landing site after fishing through the night. Collected samples were fixed in ice chest and moved to the college of Agriculture laboratory in Hadejia for observation of the stomach content.

\section{Gonadosomatic Index (GSI) determination}

The fish were sorted by species and record of the weight taken individually; the fishes were dissected laterally to expose the internal organs. The gonads were then removed and weighed. The GSI was calculated using the following formula as described by Shaheena et al. [1].

$$
\text { Gonadosomatic Index }(G S I)=\frac{\text { Weight of Gonad }}{\text { Total weight of fish }} X 100
$$

\section{Stomach content analysis}

The stomachs of the dissected fishes as stated above were removed and immediately preserved in sterile bottles containing $5 \%$ formalin. Individual stomach contents were emptied into separate petri-dishes. While some stomach contents were identified macroscopically, others were identified microscopically using a light microscope.
The component food items were identified using identification guide provided in the college of Agriculture laboratory at Hadejia. The food items encountered were analyzed using frequency of occurrence method Hynes [10] and point method Cortes [13] as stated in the formulae below.

Frequency of occurrence $=\frac{\text { Total number of stomachs withthe particular food item }}{\text { Total number of stomachs withfood }} X 100$

Percentage Point of food item $=\frac{\text { Number of point of the particular food item }}{\text { Total number of point of all food item }} X 100$

\section{Ethical statement}

Experimental procedures involving animal handling is in accordance with the standard practice as specified in the guide for handling experimental animal in University of Agriculture Makurdi, approval for this study was obtained from the Senate standing Committee on Research on behalf of the Governing council University of Agriculture Makurdi.

\section{Results}

\section{Gonado somatic index (G.S.I)}

The mean GSI for the selected fish species from the three major landing sites of Lake Kalgwai is presented in Table 1. The highest mean GSI recorded at site 1 was $6.05 \pm 0.52 \%$ for O. niloticus, followed by $S$. nigrita $(4.23 \pm 0.16 \%)$ while the least value of $2.65 \pm 0.16 \%$ was obtained for L. niloticus. In site 2 also, mean GSI was highest for 0 . niloticus with the value of $4.97 \pm 0.54 \%$ and lowest in L. niloticus $(2.40 \pm 0.12 \%)$. Similar trend was also observed for site 3 with as 0.niloticus recorded highest percentage of GSI $(6.74 \pm 0.24 \%)$ while L. niloticus also had the least value $(2.11 \pm 0.07 \%)$. The average of the mean GSI for the selected commercially exploited fish species of Kalgwai dam is presented in Table 2. The result showed significant difference $(\mathrm{P}<0.05)$ in the mean GSI of the fish species with the highest value of $5.92 \pm 0.29 \%$ recorded in O.niloticus, followed by S.nigrita and C. gariepinus $(4.50 \pm 0.14 \%)$ while the least value of $2.39 \pm 0.08 \%$ was observed in L.niloticus.

Table 1: Mean GSI across sites for selected fish species in Kalgwai Dam.

\begin{tabular}{|c|c|c|c|}
\hline \multirow{2}{*}{ Species } & \multicolumn{3}{|c|}{ Mean GSI (\%) } \\
\cline { 2 - 4 } & Site 1 & Site 2 & Site 3 \\
\hline Latesniloticus & $2.65 \pm 0.16 \mathrm{a}$ & $2.40 \pm 0.12 \mathrm{ab}$ & $2.11 \pm 0.07 \mathrm{~b}$ \\
\hline Oreochromisniloticus & $6.05 \pm 0.52 \mathrm{ab}$ & $4.97 \pm 0.54 \mathrm{~b}$ & $6.74 \pm 0.24 \mathrm{a}$ \\
\hline Mormyrusmacrophthal & $4.21 \pm 0.10$ & $4.01 \pm 0.23$ & $4.04 \pm 0.11$ \\
-mus & $4.23 \pm 0.16$ & $4.47 \pm 0.28$ & $4.81 \pm 0.23$ \\
\hline Synodotisnigrita & $2.85 \pm 0.21$ & $2.56 \pm 0.06$ & $2.52 \pm 0.08$ \\
\hline Bagrusbayad & $3.57 \pm 0.18 \mathrm{a}$ & $2.75 \pm 0.10 \mathrm{~b}$ & $2.55 \pm 0.10 \mathrm{~b}$ \\
\hline Heterotisniloticus & $3.66 \pm 0.04 \mathrm{~b}$ & $4.92 \pm 0.53 \mathrm{a}$ & $3.94 \pm 0.08 \mathrm{~b}$ \\
\hline Malapteruruselectricus & $2.69 \pm 0.13$ & $2.74 \pm 0.12$ & $2.32 \pm 0.04$ \\
\hline Clarias gariepinus & & & \\
\hline
\end{tabular}

Means in the same row of species with different superscripts differ significantly $(P<0.05)$. 
Table 2: Mean GSI for selected fish species in Kalgwai Dam.

\begin{tabular}{|c|c|}
\hline Species & Mean GSI (\%) \pm SE \\
\hline Latesniloticus & $2.39 \pm 0.08 \mathrm{~g}$ \\
\hline Oreochromisniloticus & $5.92 \pm 0.2$ \\
\hline Mormyrusmacrophthalmus & $4.09 \pm 0.0$ \\
\hline Synodotisnigrita & $4.50 \pm 0.14 \mathrm{~b}$ \\
\hline Bagrusbayad & $2.64 \pm 0.08 \mathrm{f}$ \\
\hline Heterotisniloticus & $2.95 \pm 0.11 \mathrm{e}$ \\
\hline Malapteruruselectricus & $4.18 \pm 0.20 \mathrm{c}$ \\
\hline Clarias gariepinus & $4.50 \pm 0.14 \mathrm{~b}$ \\
\hline
\end{tabular}

Means with different superscripts differ significantly $(P<0.05)$.

\section{Food and Feeding of Selected Fish Species of Kalgwai Lake}

Frequency of occurrence and percentage point of food items in the stomach of L. niloticus, O. niloticus, M. macrophthalmus, $S$. nigrita, B. bayad, H. niloticus, M. electricus, and C. gariepinus from the Lake Kalgwai is presented in Figure 1-8 respectively below. In all of the stomach sampled none was found empty. The stomach content analysis in this study distinguished the fish species into two major groups; namely carnivorous (, M. macrophthalmus and $B$. bayad) and omnivorous feeding pattern (O. niloticus, H. niloticus, M. electricus, S. nigrita and C. gariepinus), feed isolated in the stomach of the carnivores in this study includes predominantly on crustacean, fish, fish parts, mollusks, insects and insect larvae while the spectrum of feed in the stomach of omnivore were plant parts, insect parts, detritus, crustaceans, snails, worms, fish parts, insects larvae, sand/mud, and algae.

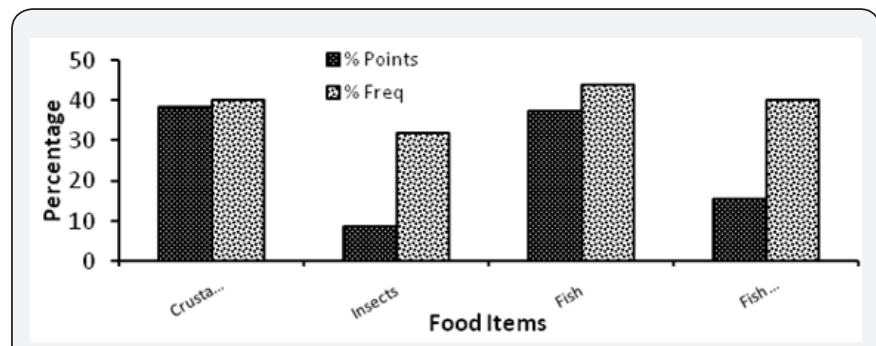

Figure 1: Percentage Frequency and points of occurrence of food items in the stomach of $L$. Niloticus found in Lake Kalgwai.

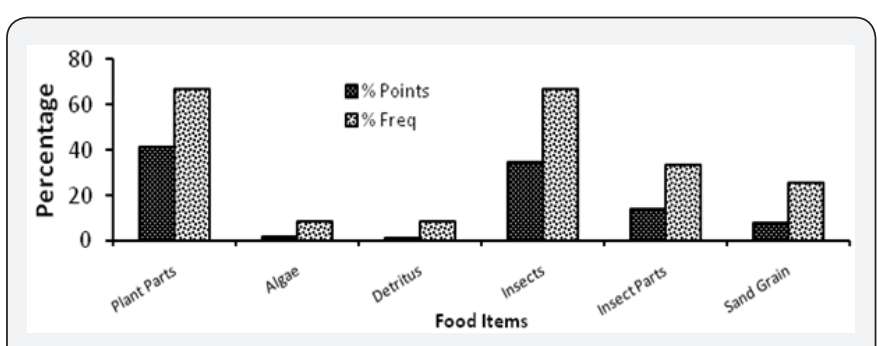

Figure 2: Percentage Frequency and points of occurrence of food items in the stomach of O. niloticus found in Lake Kalgwai.

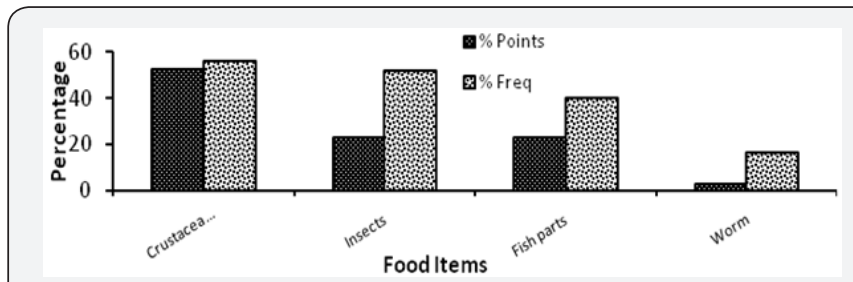

Figure 3: Percentage Frequency and points of occurrence of food items in the stomach of M.macrophthalmus found in Lake Kalgwai.

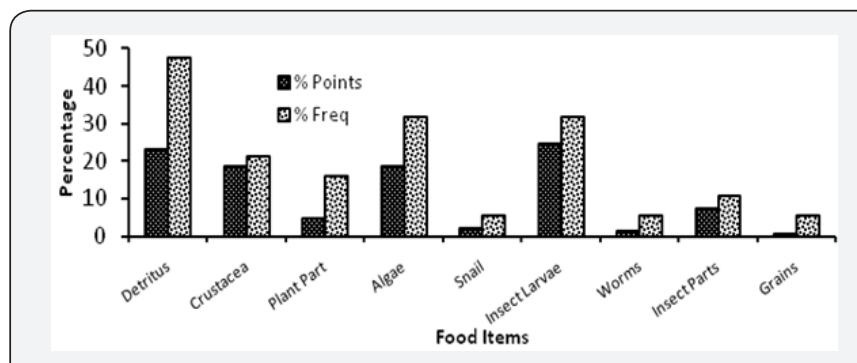

Figure 4: Percentage Frequency and points of occurrence of food items in the stomach of S. nigrita found in Lake Kalgwai.

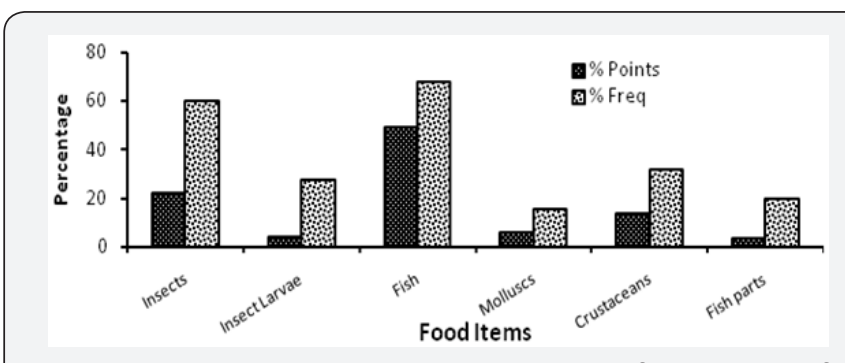

Figure 5: Percentage Frequency and points of occurrence of food items in the stomach of $B$. bayad found in Lake Kalgwai.

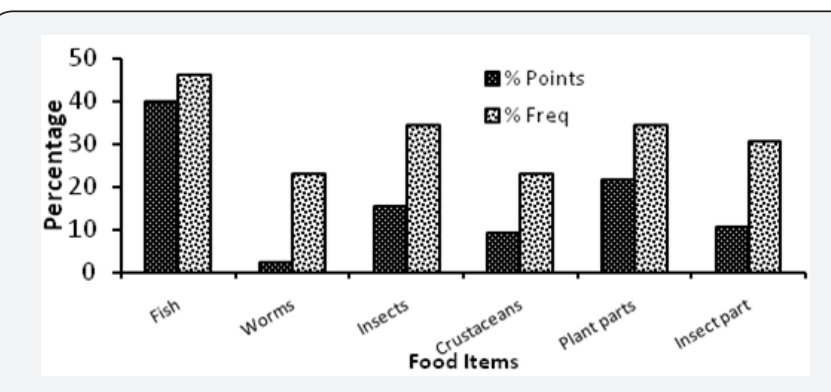

Figure 6: Percentage Frequency and points of occurrence of food items in the stomach of $\mathrm{H}$. Niloticus found in Lake Kalgwai.

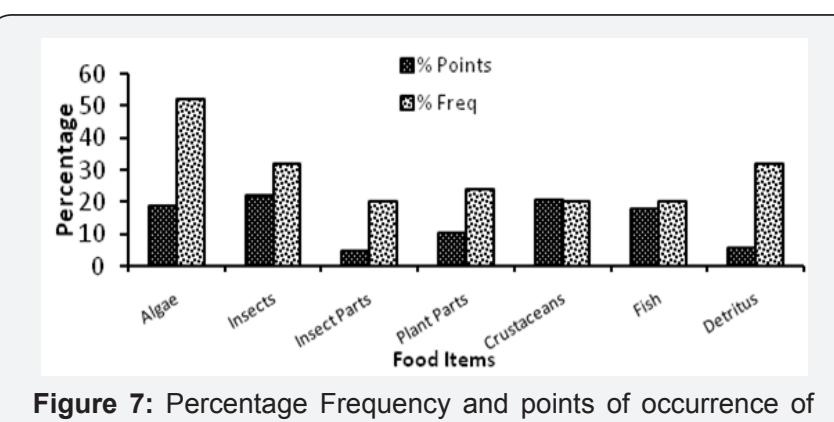

food items in the stomach of $M$. Electrics found in Lake Kalgwai. 


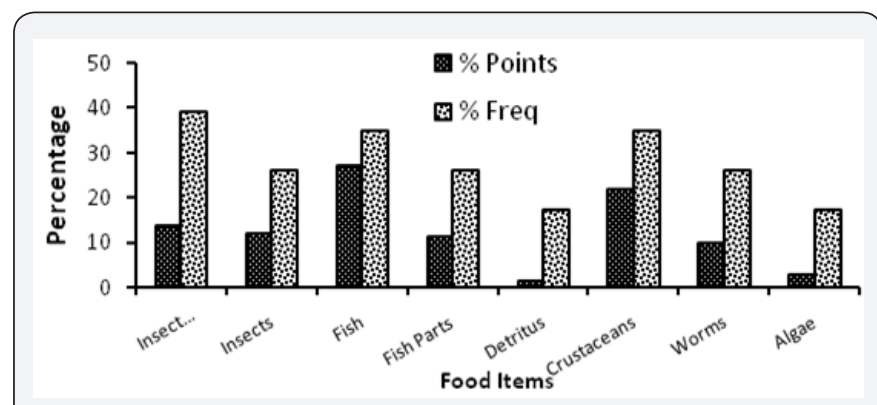

Figure 8: Percentage Frequency and points of occurrence of food items in the stomach of C. Gariepinus found in Lake Kalgwai.

\section{Discussion}

The stomach content analysis in this study revealed that none of the stomach of the sample fish species was empty, this is likely an indication of the efficiency of the sampling method used in this study, more so it could be an indication of good feeding habit adopted by the various species which enable them utilize available food item within the environment. This is similar to the findings of Olele [14] on feeding habit of Hyperopisus bebeoccidentalis Gunther, 1866 caught in Warri River, the 98\% gut fullness recorded in Olele's [14] study was attributed to the efficiency of the method of feed analysis which was presumed to have stop food digestion during sampling through the injection of formalin into the gut region of the fish. Furthermore Haroon [15] and Nwani [16] opined that the greater number of guts with food in their study was as a result of boththe feeding strategy adopted by the fishes and the abundance of food during the sampling. Contrary to these reports, Ipinjolu et al. [17] had earlier reported empty stomach in $48.1 \%$ of Mormyrusrume Valenciennes, 1847, caught in Rima River and Goronyo Dam Sokoto, also none of the species encounter had $100 \%$ stomach fullness, these observations were however, attributed to the poor feeding habit adopted by the species and also to sampling method adopted for the study. Similarly, the findings of Aramowo [18] for Citharinus species caught with gill nets in Kainji Lake revealed empty stomach in over $67 \%$ fishes sampled and was attributed to regurgitation and vomiting of the food by the fish as they struggled during their capture, he also linked result outcome to possibly inadequacy of food material during the sampling period, the differences and similarities in all of this study could be linked to differences in fish species sampled, environmental diversities and sampling methods as earlier explained.

The fishes examined in this study can be rightly separated into two distinct group based on their feeding habit, namely carnivorous and omnivorous feeding habit. Food items found in the stomach of L. niloticus, M. macrophthalmus and B. bayad shows that the species exhibit carnivorous characteristics feeding on a wide spectrum of food of animal origin (which includes crustacean, fish, fish parts, mollusks, insects and insect larvae). According to Hickley \& Bailey [19] B. bayad is described as macro-predator in River Nile (Southern Sudan) with its diet mainly consisting of fish prey, aquatic insects, organic detritus and aquatic higher plants. Bakhoum \& Samir [4] however, reported that B. bayad is carnivore, with food spectrum including cichlid fish species, insect, insectlarvae, crustaceans, amphipods and detritus. The study by Ogutu-Ohwayo [20] had concluded that larger sized L. niloticus $(>100 \mathrm{~cm})$ are mainly piscivorous. Katunzi et al. [21] also reported that stomach content analysis of Nile perch shifted from zooplankton and midge larvae, to macroinvertebrates (shrimps and dragonfly nymphs) and fish, due to size increase. Hence the differences in this study and those of the cited literature for the same species may be as a result of size variations as this study randomly but carefully selected larger sized fish of all species to give an overview of feeding habit of adult fish in the dam, more so, differences observed could also be attributed to differences in study area, or change in food availability over time.

O.niloticus, $H$. niloticus, M.electricus, $S$. nigrita and $C$. gariepinus on the other hand had food items which included plant parts, insect parts, detritus, crustaceans, snails, worms, fish parts, insect's larvae, sand/mud, and algae, this indicated that they are omnivorous feeders. The results of this study is similar to findings of Olatunde [22]. Adeyemi et al. [23] and Adeyemi [24] on the food and feeding habits of Synodontisschall and Synodontisresupinatus Boulenger [24] from Zaria area and Idah area of River Niger respectively. Oso et al. [25] had earlier stated that the ability to exploit different varieties of food items makes $O$. niloticus and Sarotherodongalilaeus Linnaeus [1] in a tropical reservoir an omnivorous feeder. Fagbenro et al. [3] also established the benthic feeding nature as well as planktonic feeding habit of Heterotisniloticus Cuvier [3] in River Oluwa and Owena Reservoir/Mahin Lagoon respectively. Ejikeet al. [26] also reported the food of Clariaslazera Valenciennes, 1840 from Jos area to be predominated by crustaceans, immature insect, bottom deposits and diatoms, hence concluded they were omnivores, the influence of environmental factor and food availability are largely the reasons for the different food item reported for these studies.

Gonadosomatic index (GSI) as observed in this study agrees with the findings of Fryer \& Isles [27] and Jhingram \& Pullin [28] who reported GSI to be between $4-20 \%$ and 3.6$37.9 \%$ respectively (at the peak of season). Shaheena et al. [1] reported that GSI fluctuates from a minimum of $2.302 \%$ in June to $11.363 \%$ in March with decrease (especially between April to June) been indication of complete spawning. Furthermore, Alam \& Pathak [29] and Mishra \& Saksena [7] also reported that GSI is synchronized with the level of maturation of fish, hence it peaks at full maturity, they further revealed that its abrupt decreased indicates beginning of spawning, although the present study focused on providing preliminary data on mean GSI, further research are recommended to further understand monthly 
variation in GSI for these commercially exploited species. The fish species investigated in this study exhibited both omnivorous and carnivorous feeding habit, feeding on a wide spectrum of food. Most of the fishes with omnivorous feeding habit have good potential for culture in captivity than the carnivorous fishes due to the expected protein requirement of animal origin, currently only Oreo chromisniloticus and Clarias gariepinus are widely cultured as one of the aquaculture candidate among the omnivorous fishes identified in this study, It is therefore recommended that more research be done on other aspect of the biology of these fishes with a view to better understand them for the sake of domestication. Meanwhile, nutritional trials can be conducted using wild juveniles and fingerlings of these species to further assess their domestication potential.

\section{References}

1. Shaheena S, Yousuf AR, Muni P (2012) Study on the fecundity of Cyprinus carpio communis (Linneaus, 1758, introduce). Int J Sci Res Pub 2(2): 1-4

2. Bakhoum SA, Samir NF (2003) Food and Feeding Habits of Bayad Fish Bagrusbayad (Forsskal, 1775) in El-NozhaHydrodrome, Alexandria Egypt. Egypt J Aqua Bio Fish 7: 197-211.

3. Fagbenro O, Adedire CO, Ayotunde EO, Faminu EO (2000) Haematological profile, food Composition and digestive enzyme assay in the gut of the African bony-tongue fish, Heterotis (Clupisudis) niloticus (Cuvier 1829) (Osteoglossidae). Trop Zoo13: 1-9.

4. Solomon SG, Okomoda VT, Aladi SL (2012) Fish fauna in lower River Niger at Idah in Kogi State. J Agri and Vet Sci 4: 34-37

5. Adeyemo OK (2004) Consequences of Pollution and Degradation of Nigerian Aquatic Environment on Fisheries Resources. The Environmentalist 23: 297-306.

6. Umaru JA, Annune PA, Cheikyula JO (2014) Food and feeding habit of some selected fish species in Doma dam Nasarawa State Nigeria. Accepted in press of the proceeding of the $28^{\text {th }}$ conference of the Fisheries Society of Nigeria.

7. Mishra S, Saksena DN (2012) Gonadosomatic Index and fecundity of an Indian major carp Labeocalbasu in Gohad reservoir. The Bioscan $7(1): 43-46$

8. Saksena DN (1987) On the use of gonado-somatic index and volume of the gonads as indicators of gonadal state in India fresh water goby, Glossogobius giuris (Ham.) with a note on the role of temperature in fish reproduction. Inter J Ich 8: 1-8.

9. Pius MO, Benedict 00 (2002) Food and Feeding inter-relationship. A preliminary indicator to the formulation of the feed of some Tilapine fishes. Trop JAni Sci 5: 35-41.

10. Hynes HBN (1950) Food of fresh water stickle backs with a review of methods used in studies of food fish. J Ani Ecol 19: 36-58.

11. Oronsaye CG, Nakpodia FA (2005) A comparative study of the food and feeding habits of Chrysichthys nigrodigitatus and Brycinus nurse in a tropical river. Pakj Sci Ind Res 48: 118-121.
12. Matthes H (1990) Report on fisheries related aspects of the HadejiaNguru wetlands conservation project. Unpublished internal report. HNWLCP, Nguru Nigeria, 250.

13. Cortes E (1997) A critical review of methods for studying fish feeding based on analysis of stomach elasmobranch Fishes, Canad J Fisheries Aqua Sci 54: 726-738.

14. Olele NF (2011) Diet Composition, Length/Weight Relationship and Condition Factor of Hyperopisus bebe occidentalis (Lacepede 1803) Caught in Warri River. Journal of Basic Applied Science Research 1: 998-1005.

15. Haroon AS (1998) Diet and Feeding ecology of two species of Barbodes gonionotus and Oreochromis species in rice field in Bangladeh. Naga the ICLARM Quarterly 21(3): 13-19.

16. Nwani CD (2004) Aspects of the biology of mormyrids in Anambra River, Nigeria. Thesis University of Nigeria Nsukka 194

17. Ipinjolu JK, Malami ZG, Hassan WA, Abubakar U (2005) Food and Feeding Habits of Elephant snout (Mormyrus rume Curvier and Valenciennes) in River Rima and Goronyo Dam in Northern Nigeria. Bull Sci Asso Nig 26: 173-185.

18. Aramowo GAO (1978) Food and Feeding of three Citharinus species in Lake Kainji,Nigerian. J Fish Bio 9: 3-10.

19. Hickley P, Bailey RG (1987) Food and feeding relationships of fish in the Sudd swamps (River Nile, southern Sudan). J Fish Bio 30: 147-159.

20. Ogutu-Ohwayo R (2004) Management of the Nile perch, Latesniloticus fishery in Lake Victoria in light of the changes in its life history characteristics. Afr J Ecol 42: 306-314.

21. Katunzi EFB, Van Densen WLT, Wanink JH, Witte F (2006) Spatial and seasonal patterns in the feeding habits of juvenile Latesniloticus (L.), in the Mwanza Gulf of Lake Victoria Hydrobiologia 568(1): 121-133.

22. Olatunde AA (1989) Some Aspects of Biology of Synodontis schall (Bloch and Schneider, 1801) in Zaria, Nigeria. J Aqu Sci 4: 49-54.

23. Adeyemi SO, Bankole NO, Adikwu IA, Akombo PM (2009) Age, Growth and Mortality of some commercially important Fish Species in Gbadikere Lake, Kogi state, Nigeria. Inter J LakRiv 2: 63-69.

24. Adeyemi SO (2010) Food and Feeding Habits of SynodontisResupinatus (Boulenger, 1904) at Idah Area of River Niger, Kogi State, Nigeria. Ani Res Inter 7(3): 1281-1286.

25. Oso JA, Ayodele IA, Fagbenro O (2006) Food and Feeding Habits of Oreochromis niloticus (L) and Sarotherodon galilaeus (L.) in a Tropical Reservoir. World J Zoo 1: 118-121.

26. Ejike C, Raji A, Anthony AD (1982) Some Aspect of Feeding and Digestion of Clariaslazera (Claridae) in Lake Kura Nigeria. (In Abstract) a paper presented at the Science Association of Nigeria conference held in Benin (1982). Book of Abstract, Abstract No. 184.

27. Fryer G, Isles TD (1972) The cichlid fishes of the great lakes of Africa. Oliver and Boyd, London, UK.

28. Jhingran VG, Pullin RSV (1985) A Hatchery Manual for the common, Chinese and Indian Major Carps. ICLARM Stud Rev 11: 1-191.

29. Alam M, Pathak JK (2010) Assessment of fecundity and gonado somatic index of commercially important fish, Labeo rohita from Ramgangariver. Inter J Pharm Bio Sci 1: 1-6. 


\section{Your next submission with Juniper Publishers} will reach you the below assets

- Quality Editorial service

- Swift Peer Review

- Reprints availability

- E-prints Service

- Manuscript Podcast for convenient understanding

- Global attainment for your research

- Manuscript accessibility in different formats

( Pdf, E-pub, Full Text, Audio)

- Unceasing customer service

Track the below URL for one-step submission https://juniperpublishers.com/online-submission.php 